\title{
North Ndebele Language
}

National Cancer Institute

\section{Source}

National Cancer Institute. North Ndebele Language. NCI Thesaurus. Code C154047.

A Niger-Congo Bantu language spoken by the Northern Ndebele people of Zimbabwe. 